\title{
FUNGAL BRAIN ABSCESS MIMICKING HIGH GRADE GLIOMA. CLINICAL CASE
}

\author{
Danius Liutkus, Darius Šilkūnas, Arnas Staškevičius \\ Klaipeda University Hospital, Department of Neurosurgery, Lithuania
}

Key words: brain abscess, fungal infection.

\section{Summary}

Intracranial brain abscess is a recess of pus in the brain [1]. Abscess may have single or multiple leasions in varies regions of the brain [1-4]. Pus is surrounded by abscess wall or capsule. The most common cause of brain abscess is bacteria, as fungal infection usually occurse in patiens with history of immunosuppression. However half of fungal infection casses, patients had no risk factors, adjacent disease or known immumosuppresion. Fungal brain abscess is rare sourse of brain abscess but frequently fatal and even for patients with no immunosuppresion [4-7]. Infection to the central nervous system spreads in several different ways. Hematogenous path from the lungs, gastrointestinal tract, or directly from the sinuses, orbits and retro-parapharingialy [4].

In this article we present a clinical case, were we first of all suspected brain tumor for the patient but later this diagnosis was denied by histological findings, whitch brought us new diagnosis fungal brain abscess.

\section{Case report}

A 62-year-old female was admitted to Klaipeda's University Hospital on 14th March 2014 from hospital with no neurosurgical team on-board. At arrival patient was complaining with a headache, episodes of loss of consciousness, tenuity, left side limbs weakness, dizziness. And those symptoms were persisting for more than 3 months. There was no history of fever or headache or focal neurological deficit, no respiratory, no gastrointestinal tract symptoms and all physical examinations before were normal.

First patients neurological evaluation was done in hospital where it was taken by ambulance after repeated loss of consciouness and examined by neurologist on duty. After full examination, head CT (Computer tomography) was done. CT demonstrated hypodense lession in the right frontal lobe and patient was transferred to neurological department, since findings on $\mathrm{CT}$ were mimicking brain tumor.
In few days MRI (Magnetic resonanse tomography) of the brain was done it showed a cerebral ring enhancement, a high signal on T2W images with little perifocal edema, radiologist's conclusion was brain tumor (picture 1).

Seeing that despite treatment patient was getting worse, she was transfered to Klaipeda's University Hospital, Neurosurgery department. On arrival patient was complaining having headache, dizziness, impaired balance and coordination, left limb paresis. Since all the physical evaluation and radiological analysis was done before admitting to the Neurosurgical department, just regular blood analysis was done and no leukocytosis, trombocytopenia, was found, just slightly anemia.

Patient was operated on 19th March 2014, no irreguliarities comparing to ordinary neoplasma extirpation was seen and there were no indications to take the crop. Removed mass was sent to histological evaluation. Patient wake up normaly with no additional neurological deficit. Postoperative CT wad done after six hours and showed no posteoperative hemorrhage (picture 2). After one day in ICU (Intensive care unit) was transfered back to Neurosurgical departent and physioterapy was initiated. In the early postoperative period left paresis regressed, gait and balance improved.

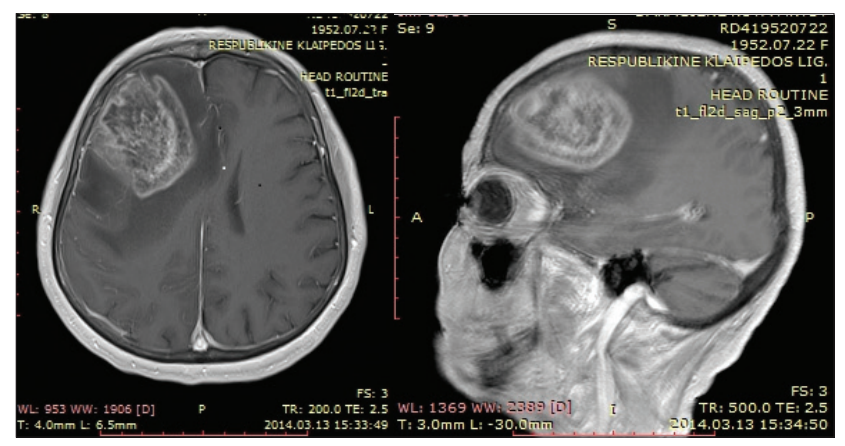

Picture 1. MRI showing a cerebral ring enhancement, a high signal on T2W images with little perifocal edema. Coronal view on the left and sagital view on the right 


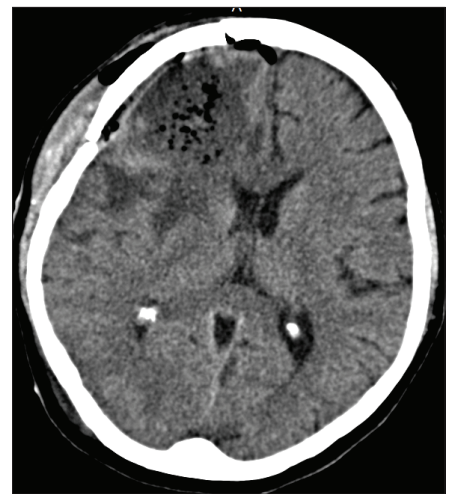

Picture 2. Postoperative CT showing that lesions mass effect is reduced and no postoperative hemorrhage

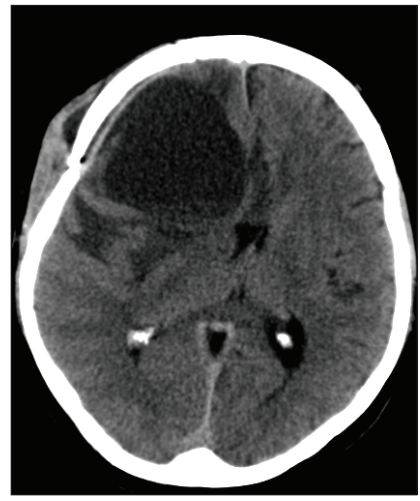

Picture 3. We see originated cyst in operated lodge area, causing compression of the brain and mass effect dislocating central brain structures

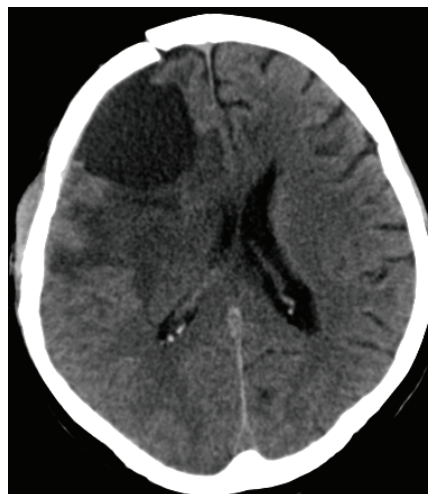

Picture 4. Cyst content is removed and lesions mass effect is reduce

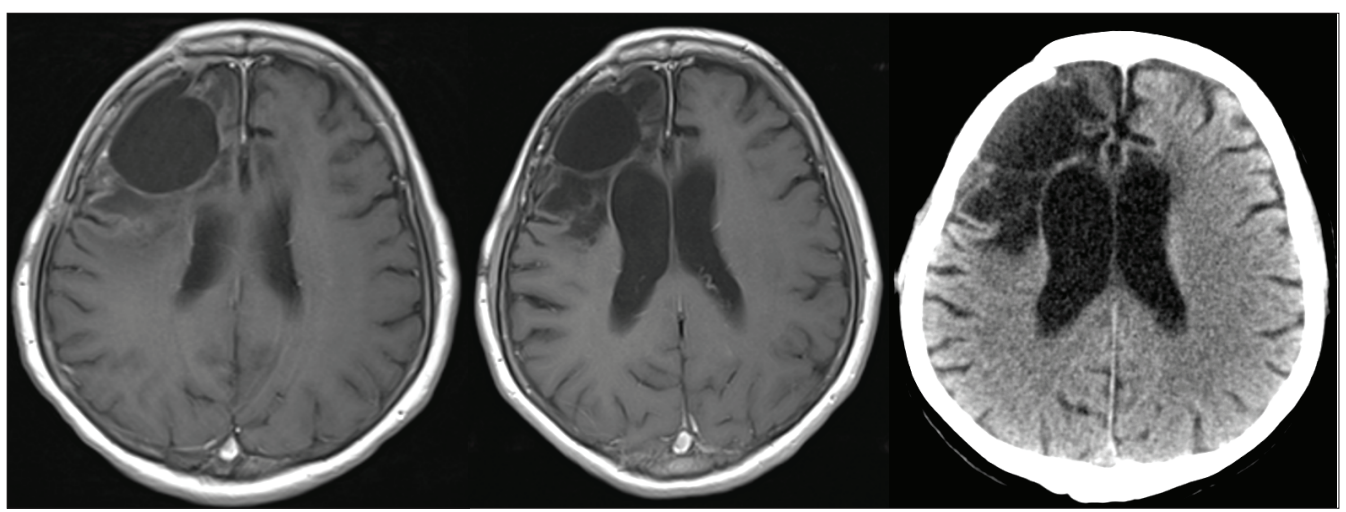

Picture 5. MRT done after 6 month Picture 6. MRT after 18 months Picture 7. Head CT after 27 months

In few days after operation, fungal abscess diagnosis came up and it made us change treatment path. We stoped treating what we thought was brain tumor and looked to fungal infection treatment optinions. Infectionist recommended Fluconasole 300mg per day until staying inpatient and six weeks outpatient.

On the 16th day after the operation, patient became disoriented, stopped walking, eating, communicating, left side paressis came out. Emergency head CT was performed and it showed - originated cyst in operated lodge area, causing compression of the brain and mass effect dislocating central brain structures (picture 3). Patient was reoperated, cyst content was removed and cysts area was connected to bassal cisterns (picture 4). Neurological deficit regressed.

Patient's follow up MRT was done after 6 and 18 months (pictures 5,6). After 27 months head CT was done and showed no progression (picture 7). After 2016 June patient stopped coming to follow up.

\section{Discussion}

Fungal infections of the brain are not assigned to a group of recorded diseases, so precise numbers of sick people through out the world is unknown. In general, fungi are found everywhere, but several forms have specific geographical spread compared with the other. There are more than 100,000 different types of fungal species and only a few hundred of them are pathogenic for humans. 10-15\% human pathological fungi are able to produce systemic CNS mycosis. Fair pathogenic fungi are as follows: Blastomycetes, Coccidioides, Paracoccidioides, Histoplasma, Sporothrix and others. They produce clinical lesions in normal individuals and then provide long term immunity to the patients recovered from the active infections. Therefore recurrense is noted. Fungal infection usually develops in the 
second and third decade of life. It is more common disease among men $[10,11]$.

Infection to the CNS spreds in several different ways. Hematogenous path from the lungs, gastrointestinal tract, or directly from the sinuses, orbits and retro-parapharingialy. Direct spreading can be determined by during trauma, applying intensive care procedures, intracranial surgery. Determining the etiological matter as fungal and not bacterial is essential, as antibacterial therapy is uneffective against fungi and CNS mycoses. Worthless selection of antibacterial therapy increases mortality and mortality [4].

The most common CNS infection - brain abscess. Less common, but ocurrs - meningitis, encephalitis, myelitis, arachnoiditis. Hemiparesis and headache are the most frequently mentioned complaints. $70-80 \%$ of cases abscess is solitary and in $52 \%$ of cases most common localization is frontal. Multiple abscesses most frequently appear in immunosuppressive patients $[6,12]$

Determination diagnosis in these patients is a significant challenge for doctors because the agent can not always be determined from blood or CSF (Cerebrospinal fluid). Specific molecular tests is needed. Surgical diagnostical approach consists of open abscess extirpation or biopsy with pus asspiration. Plus open operation gives us live wiev under microscope so we are to differentiate between necrotic lessions or pus. Radiological diagnosis based on MR imaging, indicating ring-like enhancement, a high signal on $\mathrm{T} 2 \mathrm{~W}$ images with perifocal edema and foci of restricted diffusion [8].

In our presented a clinical case, radiological images and the clinical manifestation was more similar to glioma than abscess. Nodular heterogenity on contrast injection, mimicked the images seen in the high-grade tumor. Therefore surgery or biopsy of derivative is necessary for diagnosis confirmation [8].

As the disease is relatively rare, its treatment is not standardized. Surgical and combination drug therapy is usually recomended $[1,10,13]$.Fullsolitaryabscessremovalprognosticly better than just abscess aspiration, unless we have multiple brain abscesses, and in functionally active zones $[3,6]$.

Antifungal drug combination therapy Amphotericin B, 5 -flucytosine and itraconazole is associated with better survival rates. Voriconazole can be used as an alternative to itraconazole because it penetrates the cerebrospinal fluid and brain. Medication and duration is not yet completely clear, since the registration of patients taking medication did not survive long, but a few more survivors treated with voriconazole 12 months. [9]. In our case fluconasole was choosen. Some of these drugs are nephrotoxic and renal monitoring is required.
The forecast for this disease is poor. Mortality untreated patients up to $100 \%$. Results treated somewhat more optimistic, but mortality rates remain high from $65 \%$ to $73 \%$, despite aggressive treatment. $[6,7,9,10,12]$. Interestingly, the mortality rate was not significantly different between immunosuppresive and nonimmunosuppresive patients (75 vs. $71 \%$ ) $[12,17]$. Multiple brain abscesses are more poor prognostic factor than the solitary abscess. [4,7].

\section{Conclussion}

Fungal abscess is rare disease, despite that very aggressive and with high mortality rate. Complete resection and sufficient antifungal therapy are the most recommended option for patients with fungal abscess. Unfortunately, in our case, we were unable to identify the infectious agent on the first and second operating time. Further studies are necessary to find more effective antifungal treatment for these resistant infections. Detailed research of pathophysiology, etiology and prognostic factors my lead to better survival rate.

Intracranial fungal mass lesions usually occur in immunosuppressive people but easily may appear in immunocompetive people and without any known primary focus. They can radiologically mimic CNS tumours. Intraoperative squash cytology might help in these cases.

The patient with known immunosuppression condition and detected of solitary or a multiple formations the brain parenchyma, similar to abscesses, with microheamorage, ring-like enhancement, subarachnoid haemorrhages, it is important to suspect fungal infection and ad more clinicaly important analyses when fungal abscess diagnosis comes up and start early antifungal treatment. The combination of clinical, radiological, laboratory findings, and professionals from different fields in cooperation of multidisciplinal teams can optimize patient care and succeed.

\section{References}

1. Muzumdar D, Jhawar S, Goel A. Brain abscess: An overview. International Journal of Surgery 2011; 9(2): 136-44.

http://dx.doi.org/10.1016/j.ijsu.2010.11.005

2. Oner AY, Celik H, Akpek S, Tokgoz N. Central nervous system aspergillosis: magnetic resonance imaging, diffusion- weighted imaging, and magnetic resonance spectroscopy features. Acta Radiol 2006; 47(4): 408-12. http://dx.doi.org/10.1080/02841850600580325

3. Brouwer MC, Coutinho JM, van de Beek, D. Clinical characteristics and outcome of brain abscess: Systematic review and meta-analysis. Neurology 2014; 82(9): 806-13.

4. Choudhury N, Khan AB, Tzvetanov I, Garcia-Roca R, Oberholzer J, Benedetti E. et al. Multiple aspergillus brain abscesses 
after liver transplantation. Transplantation 2014; 97:e72-e73. https:/doi.org/10.1097/TP.0000000000000174

5. Ravisankar S, Chander RV: Cerebral pheohyphomycosis: report of a rare case with review of literature. Neurol India 2013; 61: 526-528.

https:/doi.org/10.4103/0028-3886.121936

6. Revankar SG, Sutton DA, Rinaldi MG. Primary central nervous system phaeohyphomycosis : a review of 101 cases. Clin Infect Dis 2004; 38: 206-216.

https:/doi.org/10.1086/380635

7. Suri P, Chhina DK, Kaushal V, Kaushal RK, Singh J. Cerebral phaeohyphomycosis due to cladophialophora bantiana - a case report and review of literature from India. J Clin Diagn Res 8: DD01-DD05, 2014.

https:/doi.org/10.7860/jcdr/2014/7444.4216

8. Desai PA, Patel RK,Khurana N,Pandey PN. Intracranial fungal granulomas mimicking high grade gliomas. A decisive role of squash cytology (SC): a report of two cases. J Clin Diagn Res 2015 Jan;9(1).

https:/doi.org/10.7860/jedr/2015/11321.5440

9. Pooja Suri,Deepinder Kaur Chhina,Vandana Kaushal, Rakesh Kumar Kaushal, and Jasdeep Singh. Cerebral Phaeohyphomycosis due to Cladophialophora bantiana - a case report and review of literature from India J Clin Diagn Res 2014; Apr; 8(4).

10. Sharma RR, Lad SD, Pawar SJ, Gurusinghe NT, Bhagwati SN, Mahapatra AK. Surgical management of fungal infections of the central nervous system. In: Schmidek HH, Roberts DW, editors. Schmidek \& Sweet's. Operative neurosurgical techniques, indications, methods and results. 5th ed.; 2006; $1633 \mathrm{e} 71$.

11. Bauserman SC, Schochet Jr SS. Bacterial, fungal and parasitic diseases of thecentral nervous system. In: Nelson JS, Parisi JE, Schochet Jr SS, editors. Principles and practice of neuropathology. London: Mosby; 1993. 42e 74. After Liver Transplantation. Transplantation 2014; 97(12):e72.

12. Rosow L, Jiang JX, Deuel T, Lechpammer M, Zamani AA, Milner DA, et al. Cerebral phaeohyphomycosis caused by Bipolaris spicifera after heart transplantation. Transpl Infect Dis 2011; 13: 419-423.

https:/doi.org/10.1111/j.1399-3062.2011.00610.x
13. Sood S, Vaid VK, Sharma M, Bhartiya H : Cerebral phaeohyphomycosis by Exophiala dermatitidis. Indian J Med Microbiol 2014; 32:188-190.

https:/doi.org/10.4103/0255-0857.129830

14. Ochiai H, Kawano H, Minato S, Yoneyama T, Shimao Y. Cerebral phaeohyphomycosis: case report. Neuropathology 2012; 32:202-206.

https:/doi.org/10.1111/j.1440-1789.2011.01244.x

\section{GALVOS SMEGENU ABSCESAS, IMITUOJANTIS DIDELIO PIKTYBIŠKUMO GLIALINI NAVIKĄ. KLINIKINIS ATVEJIS}

D. Liutkus, D. Šilkūnas, A. Staškevičius

Raktažodžiai: grybelinè infekcija, smegenų abscesas.

Santrauka

Galvos smegenų abscesas yra pūlingas darinys, susiformavęs smegenyse. Abscesas gali būti vienoje ar keliose skirtingose galvos smegenų srityse [1]. Susiformavęs galvos smegenų abscesas dažniausia būna inkapsuliuotas. Dažniausiai minimi galvos smegenų absceso sukèlëjai yra bakterijos, o grybelinès infekcijos etiologija labiau pasitaikanti imunosupresinëje būklèje esantiems pacientams. Tačiau pusė sirgusių galvos smegenų abscesu neturèjo gretutinių ligų ar rizikos faktorių. Grybelinè galvos smegenų infekcija - reta liga, tačiau dažniausiai letali, nors ir imuninè sistema gali būti nepažeista [14,17,23]. Infekcijos patekimas ị centrinę nervų sistemą galimas keliais skirtingais keliais. Hematogeniniu keliu iš plaučių, virškinimo trakto ar tiesiogiai iš prienosinių ančių, akiduobių, užryklinio tarpo [5].

Šiame straipsnyje pateikiamas klinikinis atvejis paciento, kuriam pirmiausia buvo įtartas navikinis galvos smegenų susirgimas, kuris vèliau buvo paneigtas ir histologiškai nustatyta grybelinio galvos smegenų absceso diagnozè.

Adresas susirašinèti: daniusliu@gmail.com

Gauta 2016-11-04 